\title{
Critical Operations Capabilities and Reshoring Drivers in a High-Cost Environment
}

\author{
Cinzia SANSONE ${ }^{1}$ and Movin SEQUEIRA \\ Department of Industrial Product Development, Production and Design, School of \\ Engineering, Jönköping University, Sweden
}

\begin{abstract}
Reshoring of manufacturing to high-cost environments has been gaining attention. Several drivers are usually involved in the reshoring process. This process also requires manufacturing companies to assess their capabilities in relationship to the reshoring drivers. However, the connection between the reshoring drivers and the capabilities that the manufacturing companies have in high-cost environments has received little attention. The purpose of this study is to investigate the connection between the reshoring drivers and critical capabilities, through a transdisciplinary approach. This study was conducted through a literature review. The first step included the investigation of existing literature related to operations capabilities. The second step included the investigation of existing literature related to reshoring drivers. The third step included an investigation of the link between the critical operations capabilities and the reshoring drivers derived from the literature. Both sets of critical operations capabilities and reshoring drivers were linked based on their respective definitions. The findings revealed that there is a connection between operations capabilities and reshoring drivers. This study contributes to the development of both reshoring and operations capabilities research streams, and to practice by identifying the specific operations capabilities that can drive reshoring.
\end{abstract}

Keywords. Capabilities, reshoring, literature review, transdisciplinary

\section{Introduction}

An extensive movement of manufacturing from high-cost to low-cost environments has taken place in the last three decades [1]. The key driver for this offshoring trend has been manufacturing costs [2]. Despite achieving reduced manufacturing costs, the offshoring decisions lacked a holistic perspective while evaluation leading to suboptimal decisions [3]. These offshoring failures and changes in manufacturing strategy have led to an intensified debate about reshoring, that is when companies decide to move manufacturing back to the home country [4].

The main goal for manufacturing relocations is to achieve a competitive advantage. The fundamental strategies implemented for creating a competitive advantage are referred to as cost-leadership and differentiation [5]. Differentiation is achieved by organizing the firm around how customer value is created and delivered efficiently, and

\footnotetext{
${ }^{1}$ Corresponding Author, Mail: cinzia.sansone@ju.se.
} 
how these processes can be coordinated and managed. This is supported by the operations capabilities that the firm develops over time [6].

Relocation decisions require both current and future analysis of operations capabilities [7]. Furthermore, a large number of drivers are involved in the decision [8]. Therefore, it is fundamental to understand the connection between the operations capabilities that a company wants to develop and the reshoring drivers that a company takes into consideration when moving manufacturing back to a high-cost environment. The connection between the two research streams, that is operations capabilities and reshoring, is relevant to both research and practice. However, this connection has not been sufficiently investigated in the literature. In order to better understand this connection, it is important to adopt a transdisciplinary approach that allows investigating cross-disciplinary boundaries [9] and present findings from two disciplines with different theoretical foundations aligning the thoughts from these two disciplines. The purpose of this study is to investigate the connection between critical operations capabilities and reshoring drivers.

\section{Theoretical framework}

\subsection{Operations capabilities}

The competitive advantage is formulated as part of the business strategy and is subsequently to be transferred to the functional operations strategy. Two core elements are central to the formulation of an operations strategy [10]. The first element (competitive priorities) is a statement of what the operations function must accomplish (referred to as the tasks, objectives or priorities) and can be defined as the capabilities that the operations unit must have in order to compete successfully, given its overall business strategy. The second element in the formulation of an operations strategy (operations decisions) is the pattern of decisions that a firm makes, which determine the actual capabilities of the operations system [11]. The competitive success of a firm depends on its ability to identify, develop and continuously improve operations capabilities that provide superior value to customers. These operations capabilities can be grouped in six dimensions which are cost, quality, time, flexibility, innovation and sustainability [6].

\subsection{Reshoring drivers}

Reshoring can be described as the return of manufacturing activities back to the home country [12]. Several decision criteria influence the reshoring decision and among them include drivers, enablers and barriers. Drivers are those decision criteria that cause a reshoring action [13]. The more common groups of drivers include manufacturing cost, product or process quality, company strategies, availability and proximity to resources, and global conditions [13]. Drivers can be categorised into different theoretical frameworks, however, not all of the drivers clearly fit into these frameworks [12]. 


\subsection{Connection between operations capabilities and reshoring drivers}

The topics operations capabilities and reshoring drivers come from two different research streams, having different theoretical foundations. However, these two different research streams have one common denominator which is related to achieving competitive advantage for companies in home country. On one side, critical operations capabilities are developed in manufacturing companies as to maintain and achieve a competitive advantage. When developing these capabilities, companies can build a stronger foundation for delivering a better value to the customer (through differentiation strategies) or deliver the same value more efficiently (through low-cost strategies). On the other side, the reshoring drivers reflect on why companies reshore their manufacturing (and other operations) to high-cost countries so that they maintain and achieve a competitive advantage. Therefore, the development of operations capabilities can be related to reshoring drivers for achieving competitiveness. Manufacturing companies implementing low-cost strategy might focus on capabilities in the cost dimension, while at the same time be more sensitive to changes such as increased supply chain cost as a result of reshoring decisions. However, there is a gap in the literature regarding the connection between reshoring drivers and critical operations capabilities, that contributes to the debate of strategy versus failure in reshoring decisions [7].

\section{Research methodology}

The research was conducted in three successive steps. In the first step, a systematic search was conducted to derive the critical operations capabilities for competitive manufacturing from the literature. In the second step, another systematic search was conducted to derive the reshoring drivers from the literature. In the third step, the critical operations capabilities and reshoring drivers were mapped and the connections were analysed. Different search strings were used for the two different research streams on the Scopus database (Table 1).

Table 1. Literature review characteristics

\begin{tabular}{|c|c|c|}
\hline & Operations strategy & Reshoring \\
\hline Aim & $\begin{array}{l}\text { To derive critical capabilities for } \\
\text { competitive manufacturing }\end{array}$ & To derive common reshoring drivers \\
\hline $\begin{array}{l}\text { Search } \\
\text { string }\end{array}$ & $\begin{array}{c}\text { ("operations" OR "production" OR } \\
\text { "manufacturing" OR "supply chain" OR } \\
\text { "strategy") AND ("competitive priority" OR } \\
\text { "performance objective" OR "manufacturing } \\
\text { objective" OR "intended critical factor" OR } \\
\text { "business priority" OR "strategic priority") } \\
\text { OR ("competitive capability" OR } \\
\text { "manufacturing capability" OR "strategic } \\
\text { capability" OR "strategic dimension" OR } \\
\text { "cumulative capability" OR "dynamic } \\
\text { capability" OR "operational capability" OR } \\
\text { "realized success factor" OR "competitive } \\
\text { dimension") OR ("manufacturing strategy" } \\
\text { AND "taxonomy") }\end{array}$ & $\begin{array}{l}\text { "reshoring" OR "re-shoring" OR "reshore" } \\
\text { OR "re-shore" OR "reshored" OR "re- } \\
\text { shored" or "backshoring" OR "back- } \\
\text { shoring" OR "backshore" OR "back-shore" } \\
\text { OR "backshored" OR "back-shored" OR } \\
\text { "Rightshoring" OR "Right-shoring" OR } \\
\text { "Onshoring" OR "On-shoring" }\end{array}$ \\
\hline Database & Scopus & Scopus \\
\hline $\begin{array}{c}\text { Search } \\
\text { date }\end{array}$ & 2021-01-31 & 2021-01-31 \\
\hline
\end{tabular}




\begin{tabular}{ccc}
\hline $\begin{array}{c}\text { Search } \\
\text { period }\end{array}$ & Until 2020 & Until 2020 \\
\hline $\begin{array}{c}\text { Initial } \\
\text { sample }\end{array}$ & 3404 (including duplicates) & 1080 (including duplicates) \\
\hline $\begin{array}{c}\text { Inclusion } \\
\text { criteria }\end{array}$ & $\begin{array}{c}\text { English language journal papers that address } \\
\text { critical capabilities for competitive } \\
\text { manufacturing }\end{array}$ & $\begin{array}{c}\text { English language journal papers that address } \\
\text { reshoring drivers }\end{array}$ \\
\hline $\begin{array}{c}\text { Final } \\
\text { sample }\end{array}$ & 230 & 109 \\
\hline Synthesis & Data extraction and emerging coding (excel) & Data extraction and emerging coding (excel) \\
\hline Output & 27 Capabilities & 41 Drivers \\
\hline
\end{tabular}

The initial sample included more than 3400 articles for the operations strategy stream and more than 1000 articles for the reshoring stream. After applying different inclusion and exclusion criteria, the final sample was narrowed down to 230 papers for the operations capabilities stream and 109 papers for the reshoring stream. A content analysis of the articles included in the final sample was conducted. This analysis allowed to create two different frameworks, one summarizing the operations capabilities and one summerizing the reshoring drivers. These frameworks were then merged to identify the connection and link between operations capabilities and reshoring drivers.

\section{Findings}

\subsection{Critical operations capabilities for competitive manufacturing}

In total, 27 critical capabilities for competitive manufacturing were identified in the literature review. The operations capabilities identified in the literature are organized in six dimensions and the definitions for each capability are provided in Table 2.

Table 2. Operations capabilities

\begin{tabular}{cll}
\hline Dimension & \multicolumn{1}{c}{ Capability } & \multicolumn{1}{c}{ Definition } \\
\hline \multirow{2}{*}{ Quality } & Cost efficiency & The ability to provide products at low cost \\
\cline { 2 - 3 } & Resource efficiency & $\begin{array}{l}\text { The ability to maximize utilization of process } \\
\text { resources (machinery and human) }\end{array}$ \\
\cline { 2 - 3 } & Process efficiency & The ability to maximize the output of the process \\
\cline { 2 - 3 } & Product quality & $\begin{array}{l}\text { The ability to provide high performance and durable } \\
\text { products }\end{array}$ \\
\cline { 2 - 3 } & Service quality & The ability to provide high-performance services \\
\cline { 2 - 3 } Time & Process quality & $\begin{array}{l}\text { The ability to provide products/services with } \\
\text { consistent quality (conformance) }\end{array}$ \\
\cline { 2 - 3 } & Delivery dependability & The ability to deliver on time \\
\cline { 2 - 3 } & Brand quality & $\begin{array}{l}\text { The ability to build a strong and positive company } \\
\text { image }\end{array}$ \\
\cline { 2 - 3 } Flexibility & Supplier dependability & The ability to select and develop reliable suppliers \\
\cline { 2 - 3 } & Delivery time & The ability to deliver within a short time frame \\
\cline { 2 - 3 } & Time to market & The ability to reduce time to market \\
\cline { 2 - 3 } & Product flexibility & $\begin{array}{l}\text { The ability to customize products based on customer } \\
\text { requirements }\end{array}$ \\
\cline { 2 - 3 } & Product line flexibility & $\begin{array}{l}\text { The ability to provide a wide range of products with } \\
\text { different features }\end{array}$ \\
\cline { 2 - 3 } & Volume flexibility & The ability to respond to changes in market demand \\
\cline { 2 - 3 } & &
\end{tabular}




\begin{tabular}{lll}
\hline & Production mix flexibility & $\begin{array}{l}\text { The ability to change the product mix in } \\
\text { manufacturing }\end{array}$ \\
\cline { 2 - 3 } & Labor flexibility & $\begin{array}{l}\text { The ability of employees to perform different types of } \\
\text { tasks }\end{array}$ \\
\cline { 2 - 3 } Delivery flexibility & $\begin{array}{l}\text { The ability to change delivery times and quantities } \\
\text { within the agreed-upon delivery time }\end{array}$ \\
\cline { 2 - 3 } Innovation & Supplier flexibility & The ability to select and develop responsive suppliers \\
\cline { 2 - 3 } & Product innovation & The ability to develop and introduce new products \\
\cline { 2 - 3 } & Service innovation & The ability to develop and introduce new services \\
\cline { 2 - 3 } & Process innovation & The ability to develop and implement new processes \\
\cline { 2 - 3 } & Supply chain innovation & $\begin{array}{l}\text { The ability to develop and implement new supply } \\
\text { chain solutions }\end{array}$ \\
\cline { 2 - 3 } & Market innovation & $\begin{array}{l}\text { The ability to find and exploit new markets and } \\
\text { opportunities }\end{array}$ \\
\cline { 2 - 3 } & Technology innovation & $\begin{array}{l}\text { The ability to develop and implement new } \\
\text { technologies }\end{array}$ \\
\hline Sustainability & Product sustainability & \begin{tabular}{l} 
The ability to provide sustainable products \\
\cline { 2 - 3 }
\end{tabular} \\
\cline { 2 - 3 } & Process sustainability & $\begin{array}{l}\text { The ability to manufacture products in a sustainable } \\
\text { manner }\end{array}$ \\
\cline { 2 - 3 } & Supply chain sustainability & $\begin{array}{l}\text { The ability to source and deliver products in a } \\
\text { sustainable manner }\end{array}$ \\
\hline
\end{tabular}

\subsection{Reshoring drivers}

In total, 41 reshoring drivers were identified in the literature review (Table 3). Note that some drivers are quite similar (e.g. different elements of cost reduction), but still represent potentially distinct effects considering the extended supply chain.

Table 3. Reshoring drivers

\begin{tabular}{ll}
\hline \multicolumn{1}{c}{ Driver } & \multicolumn{1}{c}{ Definition } \\
\hline $\begin{array}{l}\text { 1. Favorable government } \\
\text { incentives }\end{array}$ & $\begin{array}{l}\text { The company seeks to take advantage of favorable government incentives } \\
\text { that are financially related. }\end{array}$ \\
\hline $\begin{array}{l}\text { 2. Favorable government } \\
\text { policies }\end{array}$ & $\begin{array}{l}\text { The company seeks to take advantage of a more favorable government } \\
\text { policy. }\end{array}$ \\
\hline $\begin{array}{l}\text { 3. Increased access to } \\
\text { energy infrastructure }\end{array}$ & $\begin{array}{l}\text { The company seeks to have better access to energy infrastructure covering } \\
\text { utilities such as electrical power. }\end{array}$ \\
\hline $\begin{array}{l}\text { 4. Increased access to } \\
\text { transportation } \\
\text { infrastructure }\end{array}$ & $\begin{array}{l}\text { The company seeks to have better access to transportation infrastructure } \\
\text { such as roads and transport services. }\end{array}$ \\
\hline $\begin{array}{l}\text { 5. Increased access to } \\
\text { production infrastructure }\end{array}$ & $\begin{array}{l}\text { The company seeks to have better access to production infrastructure such } \\
\text { as factory space. }\end{array}$ \\
\hline $\begin{array}{l}\text { 6. Increased availability } \\
\text { of production capacity }\end{array}$ & $\begin{array}{l}\text { The company seeks to utilize the existing production capacity more } \\
\text { efficiently. }\end{array}$ \\
\hline $\begin{array}{l}\text { 7. Increased availability } \\
\text { of production technology }\end{array}$ & $\begin{array}{l}\text { The company seeks to have better access to specific manufacturing } \\
\text { technologies. }\end{array}$ \\
\hline $\begin{array}{l}\text { 8. Increased availability } \\
\text { of digital technology }\end{array}$ & $\begin{array}{l}\text { The company seeks to have better access to digital technologies that are } \\
\text { increasingly being integrated into manufacturing. }\end{array}$ \\
\hline $\begin{array}{l}\text { 9. Increased delivery } \\
\text { dependability }\end{array}$ & \begin{tabular}{l} 
The company seeks to improve delivery dependability. \\
\hline $\begin{array}{l}\text { 10. Increased knowledge } \\
\text { protection }\end{array}$
\end{tabular} \\
$\begin{array}{l}\text { 11. Increased 'made-in' } \\
\text { effect }\end{array}$ & $\begin{array}{l}\text { The company seeks to improve protection for its intellectual property and } \\
\text { know-how. }\end{array}$ \\
\hline $\begin{array}{l}\text { 12. Increased process } \\
\text { quality }\end{array}$ & $\begin{array}{l}\text { The company seeks to improve its brand image through the 'made-in' } \\
\text { effect. }\end{array}$ \\
\hline $\begin{array}{l}\text { The company seeks to improve process quality in the manufacturing } \\
\text { process. }\end{array}$ \\
\hline
\end{tabular}




\begin{tabular}{|c|c|}
\hline $\begin{array}{l}\text { 13. Increased product } \\
\text { flexibility }\end{array}$ & The company seeks to improve product flexibility through customization. \\
\hline $\begin{array}{l}\text { 14. Increased product mix } \\
\text { flexibility }\end{array}$ & $\begin{array}{l}\text { The company seeks to improve product mix flexibility through increased } \\
\text { responsiveness to changes in volume and variety. }\end{array}$ \\
\hline $\begin{array}{l}\text { 15. Increased product } \\
\text { quality }\end{array}$ & The company seeks to improve product quality. \\
\hline 16. Increased servitisation & The company seeks to improve services that are related to its products. \\
\hline $\begin{array}{l}\text { 17. Increased supplier } \\
\text { dependability }\end{array}$ & The company seeks to improve supplier dependability. \\
\hline $\begin{array}{l}\text { 18. Increased supply } \\
\text { chain control }\end{array}$ & The company seeks to have better control of the upstream supply chain. \\
\hline $\begin{array}{l}\text { 19. Increased supplier } \\
\text { flexibility }\end{array}$ & $\begin{array}{l}\text { The company seeks to improve supplier flexibility through flexible } \\
\text { supplier contracts. }\end{array}$ \\
\hline $\begin{array}{l}\text { 20. Increased supply } \\
\text { chain resilience }\end{array}$ & $\begin{array}{l}\text { The company seeks to improve supply chain resilience, which is the ability } \\
\text { to recover quickly from external disruptions. }\end{array}$ \\
\hline $\begin{array}{l}\text { 21. Increased supply } \\
\text { chain sustainability }\end{array}$ & $\begin{array}{l}\text { The company seeks to improve the sustainability of the supply chain } \\
\text { associated with stricter environmental regulations. }\end{array}$ \\
\hline $\begin{array}{l}\text { 22. Increased labor } \\
\text { flexibility }\end{array}$ & $\begin{array}{l}\text { The company seeks to enforce more flexible labor contracts and flexibility } \\
\text { in hiring and firing. }\end{array}$ \\
\hline $\begin{array}{l}\text { 23. Increased access to } \\
\text { labor resources }\end{array}$ & The company seeks to improve access to highly skilled labor resources. \\
\hline $\begin{array}{l}\text { 24. Increased proximity to } \\
\text { industrial cluster }\end{array}$ & The company seeks to increase spatial proximity to an industrial cluster. \\
\hline $\begin{array}{l}\text { 25. Increased proximity to } \\
\text { R\&D }\end{array}$ & The company seeks to increase spatial proximity to its $R \& D$ function. \\
\hline $\begin{array}{l}\text { 26. Increased proximity to } \\
\text { suppliers }\end{array}$ & The company seeks to increase spatial proximity to its suppliers. \\
\hline 27. Reduced total cost & The company seeks to reduce the total costs of its business. \\
\hline $\begin{array}{l}\text { 28. Reduced } \\
\text { manufacturing cost }\end{array}$ & $\begin{array}{l}\text { The company seeks to reduce the total manufacturing costs, which includes } \\
\text { raw material, labor and energy components. }\end{array}$ \\
\hline $\begin{array}{l}\text { 29. Reduced raw material } \\
\text { cost }\end{array}$ & $\begin{array}{l}\text { The company seeks to reduce its raw material cost component of } \\
\text { manufacturing cost. }\end{array}$ \\
\hline 30. Reduced labor cost & $\begin{array}{l}\text { The company seeks to reduce the labor cost component of the } \\
\text { manufacturing cost. }\end{array}$ \\
\hline 31. Reduced energy cost & $\begin{array}{l}\text { The company seeks to reduce the energy cost component of the } \\
\text { manufacturing cost. }\end{array}$ \\
\hline $\begin{array}{l}\text { 32. } \text { Reduced } \\
\text { transportation cost }\end{array}$ & The company seeks to reduce its transportation costs. \\
\hline $\begin{array}{l}\text { 33. Reduced overhead } \\
\text { cost }\end{array}$ & $\begin{array}{l}\text { The company seeks to reduce the overhead costs which have been } \\
\text { overlooked during the offshoring process. }\end{array}$ \\
\hline $\begin{array}{l}\text { 34. Reduced coordination } \\
\text { cost }\end{array}$ & The company seeks to reduce its coordination costs in long supply chains. \\
\hline $\begin{array}{l}\text { 35. Reduced transaction } \\
\text { cost }\end{array}$ & $\begin{array}{l}\text { The company seeks to reduce its transaction costs through efficient } \\
\text { communication. }\end{array}$ \\
\hline $\begin{array}{l}\text { 36. Reduced monitoring } \\
\text { cost }\end{array}$ & The company seeks to reduce the monitoring costs. \\
\hline $\begin{array}{l}\text { 37. Improved exchange } \\
\text { rate }\end{array}$ & The company seeks to take advantage of a better exchange rate. \\
\hline $\begin{array}{l}\text { 38. Reduced delivery } \\
\text { lead-time }\end{array}$ & $\begin{array}{l}\text { The company seeks to reduce delivery lead-time as a result of shorter } \\
\text { distances and efficient transportation infrastructure. }\end{array}$ \\
\hline $\begin{array}{l}\text { 39. Reduced time-to- } \\
\text { market }\end{array}$ & $\begin{array}{l}\text { The company seeks to reduce the time-to-market during new product } \\
\text { development. }\end{array}$ \\
\hline $\begin{array}{l}\text { 40. Reduced supply chain } \\
\text { disruption }\end{array}$ & $\begin{array}{l}\text { The company seeks to reduce the negative effect of unexpected disruptive } \\
\text { events in its global supply chain. }\end{array}$ \\
\hline $\begin{array}{l}\text { 41. Reduced cultural } \\
\text { distance }\end{array}$ & The company seeks to reduce cultural distance and miscommunication. \\
\hline
\end{tabular}




\subsection{Connection between reshoring drivers and operations capabilities}

The connection between the identified reshoring drivers and operations capabilities is shown in Table 4. It can be observed that most of the reshoring drivers are related to small set of operations capabilities, which are mostly belonging to the same dimension or to dimensions which are related to each others.

Table 4. Connection between operations capabilities and reshoring drivers

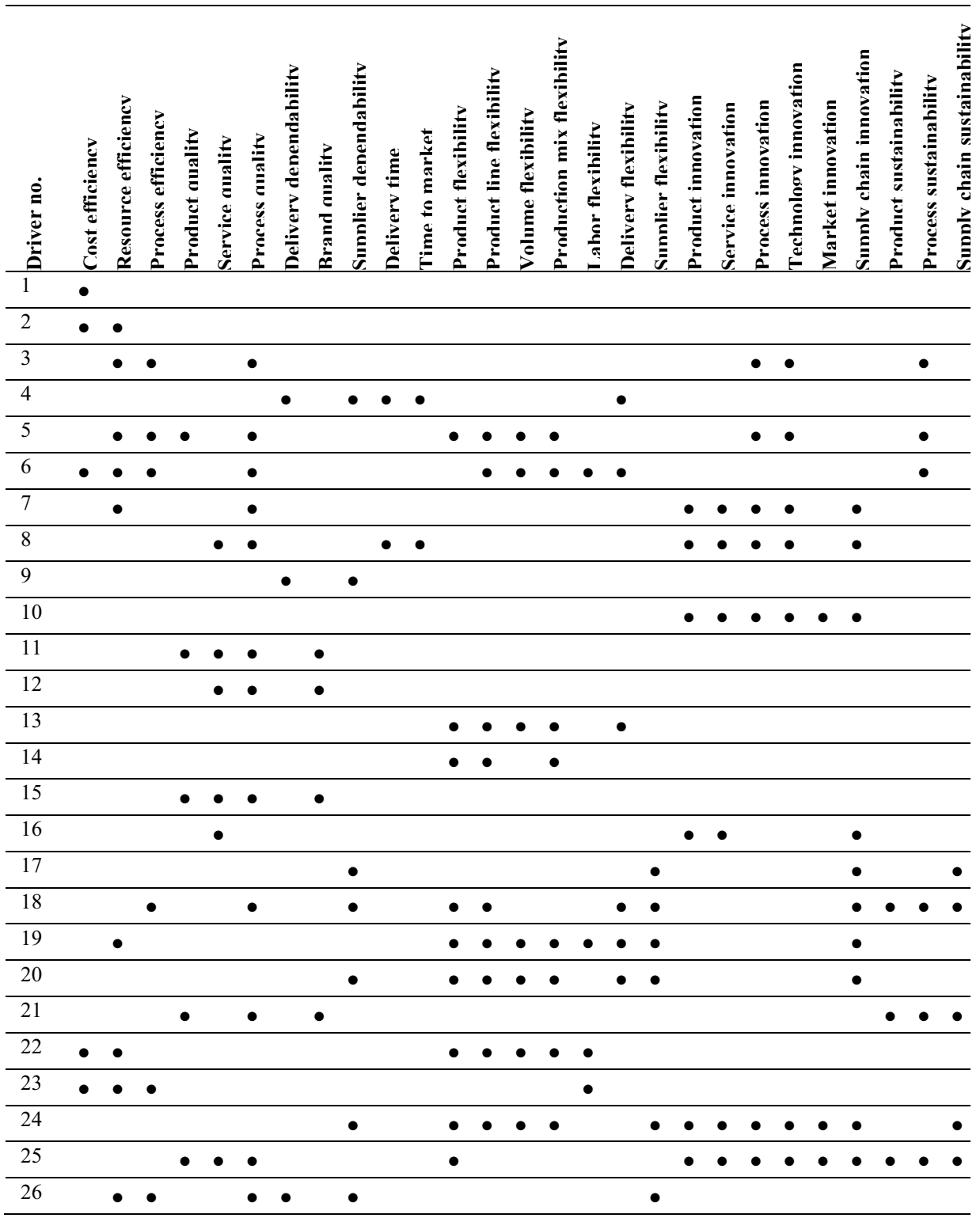




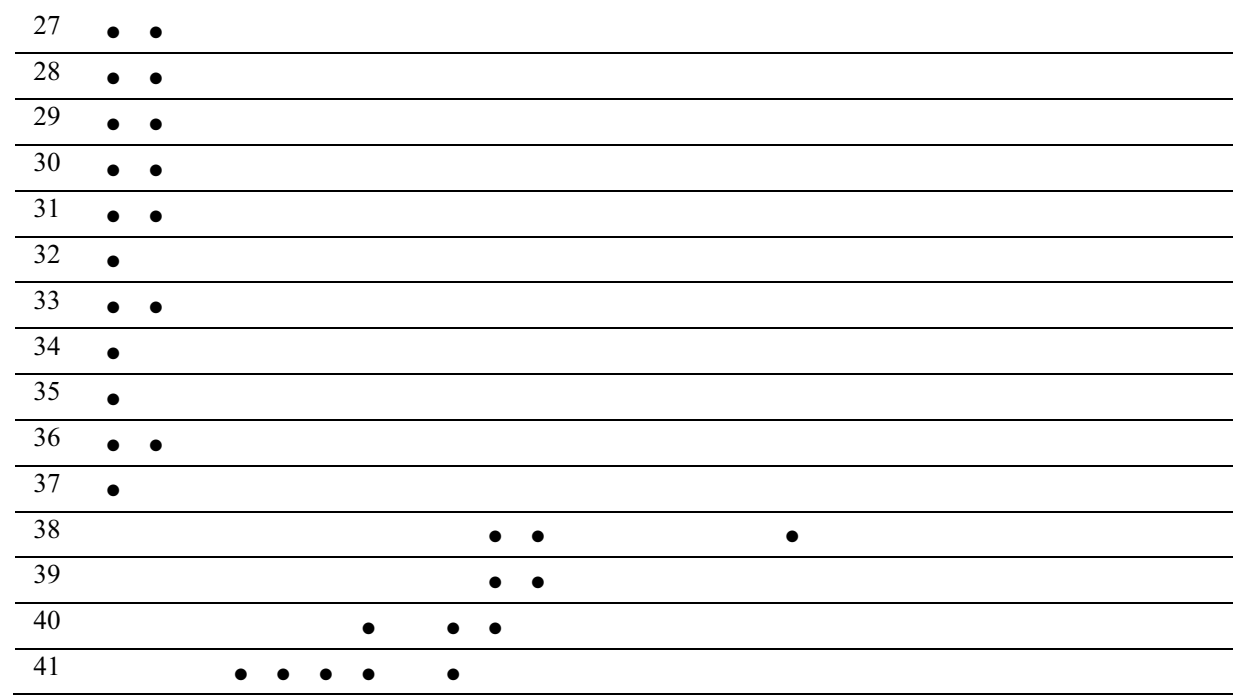

One example is given by the reshoring driver related to 'increased proximity to R\&D', when a company get closer to R\&D can improve not only the quality of the product and process, but also the innovation capabilities and sustainability capabilities depending on the priorities that the company wants to have. Another example instead is given by 'increased supply chain control' which can in turn improve capabilities related to quality, flexibility, innovation and sustainability. Companies that wants to reach a better control over the supply chain can improve their flexibility both in delivery and development but also improve supplier dependability and supply chain innovation and sustainability.

\section{Conclusion}

Based on the operations strategy implemented, manufacturing companies develop different operations capabilities. Reshoring decisions can impact and affect the development of operations capabilities, as they influence the structure of the company in terms of knowledge and resources. Moreover, the manufacturing companies develop operations capabilities in a cumulative way [14]. This is also emphasized in this study as reshoring drivers can match multiple operations capabilities belonging to one or more dimensions. Moreover, when companies need to move their production back to their home country, it is fundamental to evaluate and reorganize the capabilities needed to improve their competitiveness. Manufacturing companies need to better respond to these changes by developing critical operations capabilities.

The paper has identified the connection between operations capabilities and reshoring drivers. The contribution of the paper is both to research and practice. It advances the literature on both operations capabilities and reshoring research streams while identifying the specific operations capabilities that manufacturing companies should pursue in order to drive reshoring. The connection between these two research streams, that have different theoretical foundations, was investigated through a transdisciplinary approach [9]. 
This research paper can be considered as a starting point for building a framework for operations capabilities and reshoring drivers through a literature review. Hence, future research can strengthen the links and develop the framework further by applying it to an empirical setting, either through in-depth case studies to develop the matching more closely, or through a larger survey.

\section{References}

[1] M. Ketokivi, V. Turkulainen, T. Seppälä, P. Rouvinen, and J. Ali-Yrkkö, Why locate manufacturing in a high-cost country? A case study of 35 production location decisions, Journal of Operations Management, 2017, Vol. 49, pp. 20-30.

[2] V. Vanchan, R. Mulhall, and J. Bryson, Repatriation or reshoring of manufacturing to the US and UK: dynamics and global production networks or from here to there and back again, Growth and Change, 2018, Vol. 49, no. 1, pp. 97-121.

[3] D. Eriksson, P. Hilletofth, L. Ellram, and C. Sansone, To offshore or reshore: The battle of data points, Supply Chain Management Review, 2018, Vol. 22, No. 3, pp. 42-46.

[4] J. S. Arlbjørn and O. S. Mikkelsen, Backshoring manufacturing: Notes on an important but underresearched theme, Journal of Purchasing and Supply Management, 2014, Vol. 20, No. 1, pp. 6062.

[5] M. E. Porter, Competitive strategy: Techniques for analyzing industries and competitors, The Free Press, New York, 1980 .

[6] N. Wognum, C. Bil, F. Elgh, M. Peruzzini, J. Stjepandić, W. Verhagen, Transdisciplinary engineering research challenges, Advances in Transdisciplinary Engineering, 2018, Vol. 7, pp. 753-762.

[7] L. Bals, J. F. Kirchoff, and K. Foerstl, Exploring the reshoring and insourcing decision making process: toward an agenda for future research, Operations Management Research, 2016, Vol. 9, No. 3-4, pp. 102-116.

[8] J. V. Gray, G. Esenduran, M. J. Rungtusanatham, and K. Skowronski, Why in the world did they reshore? Examining small to medium-sized manufacturer decisions, Journal of Operations Management, 2017, Vol. 49, pp. 37-51.

[9] N. Wognum, C. Bil, F. Elgh, M. Peruzzini, J. Stjepandić, and W. J. Verhagen, Transdisciplinary systems engineering: implications, challenges and research agenda, International Journal of Agile Systems and Management, 2019, Vol. 12, No. 1, pp. 58-89.

[10] G. Dangayach and S. Deshmukh, Implementation of manufacturing strategy: a multisector study of the Indian manufacturing industry, International Journal of Services and Operations Management, 2008, Vol. 4, No. 1, pp. 1-33.

[11] J. G. Miller and A. V. Roth, A taxonomy of manufacturing strategies, Management Science, 1994, Vol. 40, No. 3, pp. 285-304.

[12] P. Barbieri, F. Ciabuschi, L. Fratocchi, and M. Vignoli, What do we know about manufacturing reshoring?, Journal of Global Operations and Strategic Sourcing, 2018, Vol. 11, No. 1, pp. 79122.

[13] M. Sequeira, P. Hilletofth, and D. Eriksson, Criteria considered in a manufacturing reshoring decision: a multiple case study, Advances in Transdisciplinary Engineering, 2020, Vol. 13, pp. 610-621.

[14] A. Größler and A. Grübner, An empirical model of the relationships between manufacturing capabilities, International Journal of Operations \& Production Management, 2006, Vol. 26, No. 5 , pp. 458-485. 